\title{
Partial or total replacement of fish meal by local agricultural by-products in diets of juvenile African catfish (Clarias gariepinus): growth performance, feed efficiency and digestibility
}

\author{
L. NYINA-WAMWIZA ${ }^{1,2}$, B. WATHELET ${ }^{3}$, J. RICHIR $^{1}$, X. ROLLIN ${ }^{4}$ \& P. KESTEMONT ${ }^{1}$ \\ ${ }^{1}$ Unit of Research in Organismal Biology, University of Namur (FUNDP), Namur, Belgium; ${ }^{2}$ Fish Culture Station of Rwasave, \\ National University of Rwanda, Butare, Rwanda; ${ }^{3}$ Laboratoire de Chimie Biologique Industrielle, Faculté des Sciences \\ Agronomiques de Gembloux, Gembloux, Belgium; ${ }^{4}$ Unité de Biochimie de la Nutrition, Faculté d'Ingénierie Biologique, \\ Agronomique et Environnementale, Louvain-la-Neuve, Belgium
}

\begin{abstract}
The study was undertaken to evaluate the growth performance and feed utilization of African catfish, Clarias gariepinus, fed six diets (D) in which fishmeal (FM) was gradually replaced by a mixture of local plant by-products. In diets 1 and 2, FM $\left(250 \mathrm{~g} \mathrm{~kg}^{-1}\right)$ was replaced by sunflower oil cake (SFOC). In diets 3 and 4, FM (250 and $150 \mathrm{~g} \mathrm{~kg}^{-1}$, respectively) was replaced by SFOC and bean meal (BM) while FM was totally substituted by a mixture of groundnut oil cake (GOC), BM and SFOC in diets 5 and 6. Sunflower oil cake was cooked, soaked or dehulled in order to determine the appropriate processing techniques for improving the SFOC nutritive value and to evaluate the apparent digestibility coefficient (ADC) values of the alternative diets. No significant differences were observed for daily feed intake, weight gain, specific growth rate (SGR) and feed efficiency (FE) among fish fed D1, D2, D3 (250 $\left.\mathrm{g} \mathrm{kg}^{-1} \mathrm{FM}\right), \mathrm{D} 4$ $\left(150 \mathrm{~g} \mathrm{~kg}^{-1} \mathrm{FM}\right)$ and D6 $\left(0 \mathrm{~g} \mathrm{~kg}^{-1} \mathrm{FM}\right)$. The highest SGR (3.2\% per day) and FE (1.2) were achieved in fish fed D3, and the lowest in fish fed D5 ( $\%$ FM), suggesting a maximum acceptable dietary concentration of hulled SFOC below $250 \mathrm{~g} \mathrm{~kg}^{-1}$ in African catfish juveniles. Protein efficiency ratio ranged from 2.2 to 3.2 for all dietary treatments and was positively influenced by FM inclusion. African catfish were able to digest plant protein very efficiently in all diets tested. ADC of protein ranged from 88.6 to $89.5 \%$, while $\mathrm{ADC}$ of energy was relatively low for diets containing hulled sunflower oilcake (71-74\%) and high when sunflower oilcake was dehulled (78.6-81.3\%). Similarly, ADC of dry matter was higher when sunflower was dehulled $(72.1 \%)$ when compared with crude SFOC (60.5\%). Soaking increased
\end{abstract}

ADC values for neutral detergent fibre (NDF), dry matter, energy, protein and amino acids (AA). There were no significant differences in protein ADCs (88-90\%) with increased levels of dietary vegetable ingredients. Both soaking and dehulling of sunflower before incorporation helped in the reduction of NDF, antitrypsin and tannins. Digestibility of all AA was generally high, greater than $90 \%$ for both indispensable and non-indispensable AA. Based on the data obtained, it was possible to totally replace menhaden fish meal with a mixture of vegetable proteins $(72 \%$ of total dietary protein) when diets contained a relatively low percentage of animal protein $(28 \%$ based on blood meal and chicken viscera meal) without negative effects.

KEY WORDS: anti-nutritional factors, apparent digestibility coefficient, Clarias gariepinus, feed utilization, growth performances, sunflower oilcake

Received 29 May 2007, accepted 3 February 2009

Correspondence: P. Kestemont, Unit of Research in Organismal Biology, University of Namur, Rue de Bruxelles 61, B-5000 Namur, Belgium. E-mail: patrick.kestemont@fundp.ac.be

\section{Introduction}

It has been shown that fishmeal constitutes the most suitable source of indispensable amino acids (IAA) for fish, given the high correlation between whole body IAA profile and the IAA requirement pattern (Mambrini \& Kaushik 1995). However, in the absence of fishmeal, it is important to evaluate the nutritional value of alternative ingredients and formulate diets based on a mixture of ingredients which can 
collectively replace fishmeal in the diet of fish. Among the many protein sources available for animal feeds in many African countries, plant proteins appear to be the most appropriate alternatives to fishmeal in fish diets, especially those that are not suitable for human consumption. Partial replacement of fishmeal by plant proteins has been accomplished in many carnivorous cultured fish (Gomes et al. 1995; Kaushik et al. 1995; Robaina et al. 1995; Masumoto et al. 1996; Hoffman et al. 1997; Fagbenro 1999), but total replacement has met with success in only a few cases (Kaushik et al. 1995; Regost et al. 1999). Some studies have also stressed that a mixture of plant protein sources is more appropriate than the incorporation of a single plant source because of improved AA profiles (Regost et al. 1999; Fournier et al. 2004; Kaushik et al. 2004).

However, use of plant-derived materials as fish feed ingredients is limited by the presence of a wide variety of anti-nutritional factors (ANFs). Some ANFs inhibit specific enzyme activities, e.g. inhibition of proteinase and amylase. Haemagglutinins and lectins are proteins which can interact in specific ways with certain carbohydrates (Hendricks 2002). Saponins and glycosides, which are bitter, reduce the palatability of livestock feeds. Some saponins reduce feed intake and growth rate of non-ruminant animals, while others are not very harmful. Phytic acid can interfere with mineral element absorption and utilization and react with proteins to form complexes which have an inhibitory effect on proteins digestion (Francis et al. 2001; Sugiura et al. 2001 in Sajjadi \& Carter 2004; Helland et al. 2006). The presence of tannins has been associated with lower nutritive value and lower biological availability of macromolecules such as proteins and carbohydrates (Desphande \& Cheryan 1985; Liener 1989 in Francis et al. 2001). Plant meals also contain starch which must be cooked to make it digestible to fish. In brief, according to Lienner (1980), Huisman et al. (1989) and Krogdahl (1989), insoluble fibres (NDF), soluble fibres (ADF), enzymes inhibitors, saponins, lectins, tannins, phytic acid and gossypol are the most important anti-nutrients acting in the gut. They affect digestive functions and nutrient absorption by altering the flow of chyme, impairing interactions between nutrients and digestive components, restricting diffusion, altering absorptive surfaces and changing microbial activity. For example, insoluble fibre appears to increase intestinal flow rate, whereas soluble fibre decreases it (Meyer et al. 1988 in Krogdahl 1989). Increased rates tend to decrease nutrient absorption (Krogdahl 1989). The consequences of such changes in the intestines on nutrient absorption and general metabolism may be large and effect on growth and production of considerable economic importance.
Attempts to increase utilization of plant protein by improving digestibility and to partly reduce the presence of ANFs include a wide range of processing techniques such as cooking, dehulling, germination, roasting, extrusion, soaking and recently extrusion cooking (Akpapunam \& Sefa-Dedeh 1997; Alonso et al. 1998, 2000; Chong et al. 2002; Egounlety \& Aworth 2003; Garg et al. 2003; Nibedita \& Sukumar 2003; Koplik et al. 2004; Gill et al. 2006). As feed formulation should be based on nutrient bioavailability, reliable data on the digestibility of different ingredients for each species might well be considered as a necessary prerequisite. However, potential interactions among ingredients should also be considered.

Fish meal (FM), the conventional dietary protein source in catfish feed (40-60\% of the total protein) (Van Weerd 1995) is totally imported in Rwanda, soybean is scarce while sunflower oil cake is available and less expensive (Nyinawamwiza et al. 2007). Moreover, it has been demonstrated that dietary incorporation of soybean meal, groundnut cake and winged bean improved the growth performance, feed intake and feed efficiency (FE) of Clarias gariepinus (Balogun \& Ologhobo 1989; Degani et al. 1989; Hoffman et al. 1997; Fagbenro 1998, 1999). Our knowledge on anti-nutrient effects in African catfish is very poor.

Based on the foregoing, several objectives were identified in this study: to evaluate, in a first experiment, the maximum level of substitution of FM in diets for juvenile African catfish when a mixture of available by-products was used and to evaluate the resulting influence on the growth response, protein utilization and FE of C. gariepinus fingerlings. Among the tested ingredients, sunflower oilcake was especially investigated by applying different processing methods such as soaking or dehulling, and by combining it with other by-products. As nutrients are not available to an animal before they are absorbed in the digestive tract, in a second stage, apparent digestibility coefficients (ADCs) for dry matter, protein, energy, fibre and AA in experimental diets was studied.

\section{Materials and methods}

\section{Fish and feeding}

Experiment 1: growth and feed utilization In the first experiment, fish were obtained by artificial reproduction from broodstock cultured in earthen ponds at the Rwasave Fish Culture Station of the National University of Rwanda (Butare District). At 3-4 g body weight, fish were acclimatized to the experimental conditions for 3 weeks in plastic tanks and received a mixture of the six experimental diets in 
order to habituate them to locally formulated feed. Fish actively ingested the food and feeding was interrupted when fish stopped eating the delivered pellets (fish were fed to appetite).

The experiment was conducted in a recirculating system including eighteen 100-L rectangular tanks installed over a $4.5-\mathrm{m}^{3}$ concrete tank for mechanical and biological water filtration. A total of 540 C. gariepinus fingerlings, with initial mean body weight of $7.49 \pm 0.09 \mathrm{~g}$, were randomly distributed as 30 fish of mixed sexes per tank. Three replicate tanks per dietary treatment were used. In all 18 tanks, water was equally aerated and exchanged at a flow rate of 2-3 $\mathrm{L} \mathrm{min}^{-1}$. Fish were subjected to natural photoperiod (12-h light and 12-h dark). Water temperature, dissolved oxygen and $\mathrm{pH}$ were checked daily. Water temperature was maintained at $23 \pm 1.5^{\circ} \mathrm{C}$, dissolved oxygen and $\mathrm{pH}$ ranged from 3.1 to $6.0 \mathrm{mg} \mathrm{L}^{-1}$ and 6.3 to 7.8 , respectively. Ammonia and nitrites were monitored twice a week and varied between $0.00-0.417$ and $0.002-0.134 \mathrm{mg} \mathrm{L}^{-1}$, respectively.

At the beginning of the experiment, 30 fish were sampled for analysis of body composition, and at the end of the experimental period, after 8 weeks, all fish were individually weighed and measured (total length). Fish were hand-fed to apparent satiation twice daily, at 9:00 and 16:00. Care was taken to stop the feed as soon as the fish stopped eating. The remaining pellets were weighed and the difference from the initial weight was then recorded as the feed intake.

Experiment 2: digestibility measurements Apparent digestibility coefficients for dry matter, protein, AA, fibre and energy of experimental diets were measured indirectly using chromic oxide $\left(\mathrm{Cr}_{2} \mathrm{O}_{3}\right)$ as an inert marker. Juveniles (initial mean body weight: $20.0 \pm 5.0 \mathrm{~g}$ ) were obtained from the Aquaculture Training and Research Centre in Tihange (Belgium). The trial was conducted in the experimental facilities at the Marcel Huet fish culture laboratory, Université Catholique de Louvain (Belgium). Fish were reared in 165-L cylindroconical tanks (water flow rate: $4 \mathrm{~L} \mathrm{~min}^{-1}$ ). Two tanks were randomly allotted to each diet. Water quality, temperature and photoperiod (LD 12:12) were in the same range as in the first experiment. The water was constantly replaced in the tank by continuous flow at a rate of $4 \mathrm{~L} \mathrm{~h}^{-1}$. Fish were acclimated in experimental tanks and to the experimental diets (Table 1) for 10 days before the start of the experiment, followed by 3 weeks of faecal collection from each tank, using an automatic faecal collector (Choubert et al. 1982). During the trial, fish were fed by hand to apparent satiation twice daily (09:00 and 17:00). About 30 min after each feeding, the tanks and the faecal collection system were brushed out to remove feed residues and faeces from the system. The faecal samples collected from each tank were frozen daily. At the end of the digestibility trial, the pooled faeces from each tank were freeze-dried prior to analysis for chromic oxide, protein, AA, fibre and energy.

\section{Experimental diets}

Six diets were formulated containing graded levels of FM. A first diet with sunflower oilcake from hulled and unsoaked seeds (SFOC) containing only $25 \%$ of FM was formulated as reference. In the second diet, SFOC was soaked in water for $24 \mathrm{~h}$ before incorporation in the diets (SFOCS) in order to diminish ANFs and to improve the feed intake (Amrish 2002). In the third diet, SFOC level was reduced and it was mixed with bean meal $(\mathrm{BM})$, Phaseolus vulgaris $(\mathrm{SFOC}+\mathrm{BM})$, in order to obtain a good balance in some essential AA, e.g. in lysine. Indeed, the lysine content of sunflower (Helianthus annuus) is low, whereas its content in methionine is high. On the contrary, the lysine content of Phaseolus seeds is relatively high, the amount ranging from 8 to $10 \mathrm{~g}$ per $16 \mathrm{~g} \mathrm{~N}$ (Abdel-El-Samei \& Lasztity 1984; Sen \& Bhattacharyya 2000; Sauvant et al. 2002). This would favourably meet the Clarias requirement for lysine estimated at $4.8 \%$ of protein for Clarias hybrids (Unprasert 1994 in Wilson 2002). Webster \& Lim (2002) found lysine to be the main limiting AA in Channel catfish Ictalurus punctatus and perhaps in other warmwater fish as well (Robinson et al. 1980 in Wilson 2002). Groundnut (Arachis hypogea) oilcake (GOC) was used as a substitute for fishmeal because of its high-crude protein content $\left(480 \mathrm{~g} \mathrm{~kg}^{-1}\right)$. Because of the potentially higher digestibility of dehulled sunflower meal/oilcake (SFOCD), and the food intake preferences (Gill et al. 2006), for the fourth diet, fishmeal was reduced to $150 \mathrm{~g} \mathrm{~kg}^{-1}$. Finally, fishmeal was reduced to $0 \%$ by using a mixture of local ingredients such as BM, GOC and SFOC. Diet $5=$ SFOCS $+\mathrm{BM}+\mathrm{GOC}$ and diet $6=\mathrm{SFOCD}+\mathrm{BM}+\mathrm{GOC}$.

Menhaden FM was obtained from Coppens International bv, Helmond, The Netherlands. Other ingredients were selected from local markets in Rwanda, partly based on their potential as cheap and readily available protein sources. All diets were analysed for proximate composition using standard methods given in AOAC (1980) and results are presented in Tables 1 and 2.

All collected ingredients were cooked in a pressure cooker for $1-2 \mathrm{~h}$ at $100{ }^{\circ} \mathrm{C}$ with addition of a few volumes of water, followed by sun drying. Before mixing, ingredients were ground, mixed thoroughly with water, made into spaghetti ( $2 \mathrm{~mm}$ diameter), and converted into pellets after sun drying.

(c) 2009 The Authors

Journal compilation (c) 2009 Blackwell Publishing Ltd Aquaculture Nutrition 


\begin{tabular}{|c|c|c|c|c|c|c|}
\hline & \multicolumn{3}{|c|}{$25 \%$ Fish meal } & \multirow{3}{*}{$\begin{array}{l}15 \% \text { Fish } \\
\text { meal } \\
\text { Diet } 4 \\
\text { SFOCD + } \\
\text { BM }\end{array}$} & \multicolumn{2}{|c|}{$0 \%$ Fish meal } \\
\hline & \multirow{2}{*}{$\frac{\text { Diet } 1}{\text { SFOC }}$} & \multirow{2}{*}{$\frac{\text { Diet } 2}{\text { SFOCS }}$} & \multirow{2}{*}{$\begin{array}{l}\text { Diet } 3 \\
\text { SFOC + } \\
\text { BM }\end{array}$} & & \multirow{2}{*}{$\begin{array}{l}\text { Diet } 5 \\
\text { SFOCS + } \\
B M+G O C\end{array}$} & \multirow{2}{*}{$\begin{array}{l}\text { Diet } 6 \\
\text { SFOCD + } \\
\text { GOC + BN }\end{array}$} \\
\hline & & & & & & \\
\hline \multicolumn{7}{|l|}{ Ingredients ( $\mathrm{g} \mathrm{kg}^{-1}$ diet) } \\
\hline Fish meal (menhaden) & 257 & 257 & 257 & 149 & 0 & 0 \\
\hline Blood meal & 89 & 89 & 89 & 99 & 99 & 99 \\
\hline Chicken viscera meal & 99 & 99 & 99 & 99 & 99 & 99 \\
\hline Sunflower oilcake & 436 & 436 & 248 & 426 & 217 & 296 \\
\hline Groundnut oilcake & 0 & 0 & 0 & 0 & 396 & 317 \\
\hline Bean meal & 0 & 0 & 197 & 137 & 99 & 99 \\
\hline Fish oil (menhaden) & 25 & 25 & 25 & 20 & 20 & 20 \\
\hline Sunflower oil (local) & 25 & 25 & 25 & 20 & 20 & 20 \\
\hline Mineral mixture ${ }^{1}$ & 30 & 30 & 25 & 20 & 20 & 20 \\
\hline Vitamin mixture ${ }^{2}$ & 30 & 30 & 25 & 20 & 20 & 20 \\
\hline Carboxymethylcellulose & 10 & 10 & 10 & 10 & 10 & 10 \\
\hline $\begin{array}{l}\text { Crude protein ( } \mathrm{g} \mathrm{kg}^{-1} \text { dry matter) } \\
\text { theoretical }\end{array}$ & 388 & 388 & 384 & 378 & 378 & 379 \\
\hline \multicolumn{7}{|l|}{ Chemical proximate composition } \\
\hline Dry matter $\left(\mathrm{g} \mathrm{kg}^{-1}\right)^{3}$ & 957 & 956 & 961 & 929 & 952 & 934 \\
\hline Crude protein $\left(\mathrm{g} \mathrm{kg}^{-1} \text { dry matter }\right)^{3}$ & 367 & 351 & 384 & 378 & 350 & 381 \\
\hline Crude fat $\left(\mathrm{g} \mathrm{kg}^{-1} \text { dry matter }\right)^{3}$ & 103 & 122 & 82 & 63 & 51 & 84 \\
\hline $\begin{array}{l}\text { Gross energy } \\
\left.\text { (kJ g }^{-1} \text { dry matter }\right)^{3}\end{array}$ & 19.0 & 18.8 & 17.8 & 17.4 & 17.5 & 18.0 \\
\hline NDF ( $\%$ dry matter) ${ }^{3}$ & 33.1 & 35.1 & 36.9 & 22.6 & 23.6 & 17.3 \\
\hline ADF ( $\%$ dry matter) ${ }^{3}$ & 13.6 & 12.1 & 10.6 & 4.7 & 10.5 & 5.1 \\
\hline Ash (\% dry matter) ${ }^{3}$ & 14.8 & 13.3 & 11.1 & 5.0 & 11.7 & 5.6 \\
\hline
\end{tabular}

Table 1 Composition of the six experimental diets

NDF, neutral detergent fibre; ADF, acid detergent fibre.

${ }^{1}$ Mineral mixture INRA Belgium, MLNP 763, (composition per kilogram: dibasic calcium phosphate: $500 \mathrm{~g}$; calcium carbonate: 215 g; sodium chloride: 40 g; potassium chloride: $90 \mathrm{~g}$; magnesium hydroxide: $124 \mathrm{~g}$; iron sulphate: $20 \mathrm{~g}$; zinc sulphate: $4 \mathrm{~g}$; manganese sulphate: $3 \mathrm{~g}$; cobalt sulphate: $0.02 \mathrm{~g}$; potassium iodide: $0.04 \mathrm{~g}$; sodium selenite: $0.03 \mathrm{~g}$ and sodium fluoride: $1 \mathrm{~g}$ ).

${ }^{2}$ Vitamin mixture INVE Aquaculture, Belgium (composition per kilogram: Vit. A: 2500000 IU; Vit. D3: 500000 IU; Vit. E : 30000 mg; Vit. K3 : 2000 mg; Vit. B1 : 2000 mg; Vit. B2 : 5000 mg; Panthotenic acid: 10000 mg; Niacin 5000 mg; Vit. B6: 4000 mg; Folic acid: 2000 mg; Vit. B12:4 mg; Vit. C: 20000 mg; Biotin: 200 mg and Inositol: 80000 mg).

${ }^{3}$ Assayed.

For the digestibility experiment, $15 \mathrm{~g} \mathrm{~kg}^{-1}$ of chromic oxide was added to the formulated diets (Table 1). The cooking procedure for diets used for the digestibility test was similar to that used for the growth experiment.

\section{Analytical methods}

Diet and faecal samples were analysed in duplicate for proximate composition (AOAC 1980) Dry matter was calculated from weight loss after drying in an oven at $105^{\circ} \mathrm{C}$ for $24 \mathrm{~h}$. Total lipids of fish carcass were extracted with chloroform/methanol/water $(10: 10: 9, \mathrm{vol} / \mathrm{vol} / \mathrm{vol})$ according to Folch et al. (1957), total nitrogen by the Kjeldahl technique (protein $=N \times 6.25$ ). Ash content was calculated from weight loss after incineration of samples in a muffle furnace for $24 \mathrm{~h}$ at $550{ }^{\circ} \mathrm{C}$.
Gross energy of the diets and faeces was determined using an adiabatic bomb calorimeter 1241, Parr Instrument Company, Moline-Illinois-USA). Neutral detergent fibre (NDF) and acid detergent fibre (ADF) in diets and faeces were measured by the method of Goering \& van Soest (1970).

Chromic oxide was estimated spectophotometrically following the method of Furukawa \& Tsukahara (1966).

Total AA contents of diets (Table 2) and faecal samples from each tank were measured by ion-exchange chromatography, Biochrom 20 Plus-Amino Acid Analyser, Biochrom Ltd, Cambridge, UK. (Moore et al. 1958). For sulphur AA, samples were first oxidized by a performic acid-phenol to oxidize methionine and cystine to methionine sulphone and cysteic acid, respectively (Lewis 1966). These oxidized samples, as well as unoxidized samples, were hydrolysed in $6 \mathrm{~N}$ $\mathrm{HCl}$, for $24 \mathrm{~h}$ at $110^{\circ} \mathrm{C}$. Norleucine was used as an internal 
Table 2 Proximate amino acids composition of the experimental diets (g per $16 \mathrm{~g} \mathrm{~N}$ )

\begin{tabular}{|c|c|c|c|c|c|c|}
\hline \multirow[b]{3}{*}{$\begin{array}{l}\text { Amino acid } \\
\text { (\% dry matter) }\end{array}$} & \multicolumn{3}{|c|}{$25 \%$ Fish meal } & \multirow{3}{*}{$\begin{array}{l}\frac{15 \% \text { Fish meal }}{\text { Diet } 4} \\
\text { SFOCD }+ \\
\text { BM }\end{array}$} & \multicolumn{2}{|c|}{$0 \%$ Fish meal } \\
\hline & Diet 1 & Diet 2 & Diet 3 & & Diet 5 & Diet 6 \\
\hline & SFOC & SFOCS & $\begin{array}{l}\mathrm{SFOC}+ \\
\mathrm{BM}\end{array}$ & & $\begin{array}{l}\mathrm{SFOCS}+ \\
\mathrm{BM}+\mathrm{GOC}\end{array}$ & $\begin{array}{l}\mathrm{SFOCD}+ \\
\mathrm{GOC}+\mathrm{BM}\end{array}$ \\
\hline Alanine & 5.67 & 5.69 & 5.72 & 5.28 & 4.92 & 4.90 \\
\hline Arginine $^{1}$ & 5.96 & 6.04 & 5.86 & 7.00 & 8.09 & 8.23 \\
\hline Aspartic acid/Asparagine & 9.85 & 9.89 & 10.19 & 10.18 & 11.31 & 10.90 \\
\hline Cystein/Cystine & 1.06 & 1.01 & 1.03 & 1.22 & 1.20 & 1.22 \\
\hline Glutamic acid/Glutamine & 16.80 & 16.68 & 16.16 & 19.14 & 18.76 & 20.01 \\
\hline Glycine & 6.02 & 6.05 & 5.89 & 5.70 & 5.60 & 5.58 \\
\hline Histidine $^{1}$ & 2.89 & 2.82 & 2.87 & 3.02 & 3.26 & 3.22 \\
\hline Isoleucine $^{1}$ & 3.27 & 3.29 & 3.31 & 3.35 & 2.88 & 3.12 \\
\hline Leucine $^{1}$ & 7.59 & 7.57 & 7.76 & 7.46 & 7.57 & 7.43 \\
\hline Lysine $^{1}$ & 6.65 & 6.50 & 6.97 & 5.83 & 5.37 & 5.17 \\
\hline Methionine ${ }^{1}$ & 2.07 & 1.98 & 2.16 & 2.03 & 1.42 & 1.56 \\
\hline Phenylalanine $^{1}$ & 4.36 & 4.27 & 4.53 & 4.76 & 5.14 & 4.93 \\
\hline Proline & 4.89 & 4.84 & 4.85 & 4.73 & 4.93 & 4.79 \\
\hline Serine & 4.68 & 4.78 & 4.94 & 4.95 & 5.23 & 5.09 \\
\hline Threonine $^{1}$ & 4.21 & 4.22 & 4.32 & 4.14 & 3.87 & 3.85 \\
\hline Tyrosine & 2.60 & 2.56 & 2.72 & 2.73 & 3.09 & 2.95 \\
\hline Valine $^{1}$ & 5.04 & 5.06 & 5.12 & 5.04 & 5.14 & 5.03 \\
\hline
\end{tabular}

Tryptophan was not analysed.

${ }^{1}$ Indispensable amino acid (IAA). standard and sodium citrate $(\mathrm{pH} 2.2)$ as a buffer solution. The AA were post-column derivatized with ninhydrin and quantified at $570 \mathrm{~nm}$ for primary AA and $440 \mathrm{~nm}$ for secondary (imino acid, proline and hydroxy-proline). Tryptophan could not be analysed because of its destruction during acid hydrolysis.

Among the multiple ANFs that can be found in the vegetable ingredients used in the experimental diets and in the diets themselves, three were measured: antitrypsin, tannins and phytic acid. These three factors were measured by spectrophotometry.

The principle of the proportion of the antitrypsin is based on the release of $p$-nitroaniline from $N$-benzoyl-DLarginine- $p$-nitroanilide (BAPNA), this being immediately followed by an increase of extinction measured at $407 \mathrm{~nm}$ during $10 \mathrm{~min}$ against a reagent blank. The protocol of proportion has been established according to the method of Bergmeyer (1965). Trypsin inhibition was expressed in International Unit (IU), an antitrypsin unit being equal to a difference of absorbance $\Delta \mathrm{DO}$ of 0.001 , in the experimental conditions.

Tannins present in the vegetable by-products were quantified by measuring their absorbance at $550 \mathrm{~nm}$ against a reagent blank after their extraction by means of organic solvents in acid medium, and the reaction of these polyphenols with hydrated ammonium ferric sulphate $\mathrm{NH}_{4} \mathrm{Fe}\left(\mathrm{SO}_{4}\right)_{2} \cdot 12 \mathrm{H}_{2} \mathrm{O}$. The protocol of proportion used has been modified from Aganda \& Mosase (2001). Tannin contents were expressed in gram of catechin equivalent per kilogram of sample analysed, catechin being the standard tannin used.

Phytic acid contents were determined according to the method of March et al. (1995). The method of proportion consists firstly in isolating phytates, after their extraction in sulphuric acid, in the form of iron (III) phytate. Secondly, $\mathrm{NaOH}$ and water were added to this solid iron (III) salt in order to precipitate hydrated iron (III) oxide and liberate the phytate. The absorbance was measured at $400 \mathrm{~nm}$ against a reagent blank. Phytic acid contents were expressed as grams of phytic acid per kilogram of sample analysed.

\section{Data processing and statistical analysis}

Fish performance was determined using the following formulae:

$$
\text { Weight gain }(\%)=100 \times\left(W_{f}-W_{i}\right) / W_{i}
$$

where $W_{i}$ and $W_{f}$ is the initial and final body mass (g).

$$
\begin{aligned}
& \text { Specific growth rate }(\mathrm{SGR}, \% \text { per day) } \\
& =100 \times\left[\ln \left(W_{f}\right)-\ln \left(W_{i}\right)\right] / \Delta t
\end{aligned}
$$

where $W_{i}$ and $W_{f}$ is the initial and final mean body mass (g) and $\Delta t$ is the duration of experiment.

$$
\text { Feed efficiency }(\mathrm{FE})=(\mathrm{FB}-\mathrm{IB}) / \mathrm{TFI}
$$

where $\mathrm{FB}$ is the final biomass per tank (g), IB is the initial biomass per tank $(\mathrm{g})$ and TFI is the total food intake $(\mathrm{g})$. 
Protein efficiency ratio (PER)

$=$ Weight gain $(\mathrm{g}) /$ protein intake $(\mathrm{g})$

The ADC of dry matter were calculated according to Maynard and Loosly (1969) in Burel et al. (2000) as follows:

ADC dry matter $(\%)=100 \times[1-(\mathrm{Di}) /(\mathrm{Fi})]$

The ADCs of proteins, AA, fibre and energy were calculated as follows (Cho \& Slinger 1979):

$$
\mathrm{ADC}=100 \times[1-(F / D) \times(\mathrm{Di} / \mathrm{Fi})]
$$

where $D$ is the dietary nutrient or energy content $(\%), F$ is the faecal nutrient or energy content (\%), Di is the dietary marker content $(\%)$ and $\mathrm{Fi}$ is the faecal marker content $(\%)$.

All data were analysed by one-way analysis of variance (ANOVA) followed by Fisher test LSD (least significant difference) to determine if significant differences occurred among the dietary treatments. Variance homogeneity was first checked by Hartley test (Dagnelie 1975). Differences were considered significant at $P<0.05$.

\section{Results}

\section{Growth and feed efficiency}

As shown in Table 3, daily voluntary feed intake decreased with increase in dietary plant protein. This was significantly lowest in diet $5(P<0.05)$ when FM was totally replaced by a mixture of plant by-products in a diet containing hulled sunflower oil cake.

At the end of the experiment, a significant decrease in weight gain was observed between groups of fish fed diet 5 and those fed other diets. In contrast, no significant differences were obtained between fish fed diet 6 containing dehulled SFOC $(0 \%$ FM) and fish fed diets containing 15 or $25 \%$ FM. On the contrary, the best overall growth response was obtained in fish fed diet 3 (25\% fishmeal when SFOC was reduced to $25 \%$ ). Similar results were observed for $\mathrm{FE}$ and PER with a significant reduction observed for diet 5. No significant differences were observed between fish fed diets 1 and 2 containing unsoaked and soaked SFOC, respectively.

\section{Apparent digestibility coefficients}

Apparent digestibility coefficients for dry matter, protein, energy, fibre and AA in diets consumed by $C$. gariepinus fingerlings are shown in Table 4. ADCs of dry matter and gross energy were significantly affected by experimental diets $(P<0.05)$, generally high for the diets containing dehulled SFOC and especially lowered by increased inclusion of hulled SFOC meal in the diet. Diet 3 gave intermediate results. Dry matter digestibility was highest in diet 4 followed by diet 6, whereas diet 1 gave the lowest ADC. Dehulling increased ADC of gross energy and insoluble fibres (NDF) in diets 4 and 6, whereas it was lowest in diet 5. In comparing diets 1 and 2, soaking process increased ADC values of NDF, dry matter, gross energy, protein and AA ADCs. There were no significant differences in ADCs $(88-90 \%)$ of protein with increased level of vegetable ingredients in diets $(>0.05)$. Digestibilities of all AA were generally high, over $90 \%$ for indispensable and nonindispensable AA little affected by experimental diet. Indeed, digestibilities of three IAA (isoleucine, methionine and threonine) were higher in diets 1 and 2 , but lower in diet 5 .

Table 3 Growth performance and feed efficiency of Clarias gariepinus fingerlings fed experimental diets for 61 days

\begin{tabular}{|c|c|c|c|c|c|c|}
\hline \multirow[b]{3}{*}{ Parameters } & \multicolumn{3}{|l|}{$25 \%$ Fish meal } & \multirow{3}{*}{$\frac{15 \% \text { Fish meal }}{\text { Diet } 4} \frac{\text { SFOCD }+ \text { BM }}{}$} & \multicolumn{2}{|l|}{$0 \%$ Fish meal } \\
\hline & Diet 1 & Diet 2 & Diet 3 & & Diet 5 & Diet 6 \\
\hline & SFOC & SFOCS & $\mathrm{SFOC}+\mathrm{BM}$ & & $\mathrm{SFOCS}+\mathrm{BM}+\mathrm{GOC}$ & $\mathrm{SFOCD}+\mathrm{GOC}+\mathrm{BM}$ \\
\hline Initial body weight (g) & $7.54 \pm 0.08$ & $7.51 \pm 0.02$ & $7.56 \pm 0.04$ & $7.44 \pm 0.09$ & $7.43 \pm 0.03$ & $7.45 \pm 0.04$ \\
\hline Final body weight $(\mathrm{g})$ & $42.8 \pm 13.1^{\mathrm{ab}}$ & $42.1 \pm 9.7^{\mathrm{ab}}$ & $53.3 \pm 11.8^{a}$ & $38.7 \pm 2.3^{a b c}$ & $26.0 \pm 4.4^{c}$ & $35.6 \pm 5.1^{b c}$ \\
\hline Weight gain $(\%)$ & $468 \pm 173^{\mathrm{ab}}$ & $460 \pm 129^{a b}$ & $604 \pm 154^{a}$ & $419 \pm 259^{\mathrm{ab}}$ & $250 \pm 637^{b}$ & $377 \pm 710^{\mathrm{ab}}$ \\
\hline $\operatorname{SGR}(\%)$ & $2.80 \pm 0.50^{\mathrm{ab}}$ & $2.79 \pm 0.39^{\mathrm{ab}}$ & $3.17 \pm 0.38^{a}$ & $2.70 \pm 0.08^{\mathrm{ab}}$ & $2.04 \pm 0.31^{\mathrm{b}}$ & $2.55 \pm 0.26^{\mathrm{ab}}$ \\
\hline $\begin{array}{l}\text { Daily feed intake } \\
\left(\mathrm{g} \text { fish }^{-1} \text { day }^{-1} \text { ) }\right.\end{array}$ & $0.51 \pm 0.12^{\mathrm{a}}$ & $0.51 \pm 0.10^{\mathrm{a}}$ & $0.62 \pm 0.10^{a}$ & $0.47 \pm 0.02^{\mathrm{a}}$ & $0.40 \pm 0.04^{b}$ & $0.48 \pm 0.05^{a}$ \\
\hline Feed efficiency & $1.09 \pm 0.16^{\mathrm{ab}}$ & $1.08 \pm 0.12^{\mathrm{ab}}$ & $1.16 \pm 0.14^{a}$ & $1.04 \pm 0.03^{\mathrm{ab}}$ & $0.74 \pm 0.12^{\mathrm{b}}$ & $0.87 \pm 0.10^{\mathrm{ab}}$ \\
\hline Protein efficiency ratio & $3.11 \pm 0.47^{a}$ & $3.22 \pm 0.37^{a}$ & $3.16 \pm 0.39^{a}$ & $2.97 \pm 0.08^{a b}$ & $2.21 \pm 0.37^{c}$ & $2.45 \pm 0.27^{b c}$ \\
\hline
\end{tabular}

Values are given as mean \pm standard deviation. Values in the same row with common superscript letters are not significantly different $(P<0.05)$ 
Table 4 Apparent digestibility coefficients (\%) for dry matter, crude protein, gross energy, NDF, ADF and amino acids in African catfish fed various local levels of vegetable protein in substitution of menhaden fish meal

\begin{tabular}{|c|c|c|c|c|c|c|}
\hline \multirow[b]{3}{*}{ Parameters } & \multicolumn{3}{|c|}{$25 \%$ Fish meal } & \multirow{3}{*}{$\frac{\frac{15 \% \text { Fish meal }}{\text { Diet } 4}}{\text { SFOCD + BM }}$} & \multicolumn{2}{|l|}{$0 \%$ Fish meal } \\
\hline & \multirow{2}{*}{$\begin{array}{l}\text { Diet } 1 \\
\text { SFOC }\end{array}$} & \multirow{2}{*}{$\begin{array}{l}\text { Diet } 2 \\
\text { SFOCS }\end{array}$} & \multirow{2}{*}{$\frac{\text { Diet } 3}{}$} & & \multirow{2}{*}{$\begin{array}{l}\text { Diet } 5 \\
\text { SFOCS + BM + } \\
\text { GOC }\end{array}$} & \multirow{2}{*}{$\begin{array}{l}\text { Diet } 6 \\
\text { SFOCD + GOC + } \\
\text { BM }\end{array}$} \\
\hline & & & & & & \\
\hline Digestibility of dry matter (\%) & $60.5 \pm 1.3^{c}$ & $64.2 \pm 1.1^{\mathrm{bc}}$ & $67.1 \pm 1.4^{\mathrm{ab}}$ & $72.1 \pm 1.9^{a}$ & $65.0 \pm 4.4^{\mathrm{bc}}$ & $70.9 \pm 2.6^{\mathrm{ab}}$ \\
\hline Digestibility of crude protein (\%) & $87.7 \pm 3.0$ & $88.8 \pm 0.6$ & $87.6 \pm 0.8$ & $88.5 \pm 1.8$ & $88.0 \pm 0.8$ & $89.5 \pm 0.5$ \\
\hline Digestibility of gross energy (\%) & $72.4 \pm 1.9^{b c}$ & $74.4 \pm 0.6^{\mathrm{bc}}$ & $77.0 \pm 2.5^{\mathrm{ab}}$ & $81.3 \pm 0.7^{a}$ & $71.0 \pm 3.9^{c}$ & $78.6 \pm 2.9^{\mathrm{a}}$ \\
\hline Digestibility of NDF (\%) & $44.3 \pm 1.1^{\mathrm{e}}$ & $52.2 \pm 0.7^{c}$ & $61.6 \pm 1.1^{\mathrm{b}}$ & $65.9 \pm 0.1^{\mathrm{a}}$ & $41.8 \pm 1.4^{f}$ & $49.9 \pm 1.2^{d}$ \\
\hline \multicolumn{7}{|l|}{ Amino acids (\%) } \\
\hline Alanine & $92.6 \pm 0.8$ & $93.0 \pm 0.3$ & $93.0 \pm 0.5$ & $91.2 \pm 0.6$ & $91.2 \pm 1.8$ & $89.3 \pm 1.7$ \\
\hline Arginine $^{1}$ & $94.5 \pm 1.6$ & $95.4 \pm 0.4$ & $94.0 \pm 0.5$ & $95.2 \pm 0.9$ & $95.6 \pm 0.4$ & $96.1 \pm 0.7$ \\
\hline Aspartic acid/Asparagine & $90.1 \pm 1.4$ & $90.9 \pm 0.5$ & $89.1 \pm 0.5$ & $90.3 \pm 1.2$ & $90.7 \pm 1.9$ & $91.9 \pm 1.2$ \\
\hline Cystein/Cystine & $80.2 \pm 4.1$ & $79.8 \pm 2.3$ & $77.0 \pm 0.4$ & $83.2 \pm 2.3$ & $82.6 \pm 1.2$ & $84.7 \pm 2.1$ \\
\hline Glutamic acid/Glutamine & $93.4 \pm 1.3$ & $94.0 \pm 0.5$ & $92.1 \pm 0.8$ & $93.8 \pm 1.2$ & $93.2 \pm 1.7$ & $94.4 \pm 1.5$ \\
\hline Glycine & $89.3 \pm 2.1$ & $90.2 \pm 1.2$ & $89.2 \pm 1.0$ & $89.8 \pm 1.5$ & $86.2 \pm 2.7$ & $88.8 \pm 2.2$ \\
\hline Histidine $^{1}$ & $92.0 \pm 0.4$ & $92.8 \pm 0.2$ & $91.7 \pm 0.1$ & $92.2 \pm 0.7$ & $91.0 \pm 0.6$ & $92.5 \pm 2.0$ \\
\hline Isoleucine $^{1}$ & $90.6 \pm 1.5^{\mathrm{a}}$ & $91.0 \pm 1.0^{\mathrm{a}}$ & $88.4 \pm 0.4^{\mathrm{ab}}$ & $89.1 \pm 1.0^{\mathrm{ab}}$ & $86.8 \pm 0.6^{\mathrm{b}}$ & $88.8 \pm 1.0^{\mathrm{ab}}$ \\
\hline Leucine $^{1}$ & $92.8 \pm 1.0$ & $93.0 \pm 0.6$ & $91.4 \pm 0.6$ & $91.6 \pm 0.9$ & $90.1 \pm 1.9$ & $95.0 \pm 0.8$ \\
\hline Lysine $^{1}$ & $94.3 \pm 1.0$ & $94.5 \pm 0.6$ & $93.0 \pm 0.6$ & $93.1 \pm 0.8$ & $91.1 \pm 1.3$ & $92.2 \pm 1.1$ \\
\hline Methionine ${ }^{1}$ & $92.2 \pm 1.1^{\mathrm{a}}$ & $91.8 \pm 0.1^{\mathrm{a}}$ & $90.2 \pm 0.2^{\mathrm{ab}}$ & $91.6 \pm 0.9^{a}$ & $87.6 \pm 1.0^{b}$ & $90.7 \pm 0.3^{a b}$ \\
\hline Phenylalanine $^{1}$ & $92.0 \pm 1.5$ & $92.8 \pm 0.5$ & $90.8 \pm 0.5$ & $90.6 \pm 1.2$ & $92.1 \pm 1.8$ & $91.8 \pm 1.1$ \\
\hline Proline & $92.1 \pm 2.0$ & $92.8 \pm 0.7$ & $91.4 \pm 1.1$ & $92.0 \pm 1.1$ & $90.7 \pm 1.4$ & $91.9 \pm 2.0$ \\
\hline Serine & $90.5 \pm 1.9$ & $91.4 \pm 0.8$ & $90.1 \pm 0.8$ & $90.9 \pm 1.0$ & $89.6 \pm 2.2$ & $91.1 \pm 1.7$ \\
\hline Threonine ${ }^{1}$ & $90.8 \pm 1.1^{\mathrm{a}}$ & $91.3 \pm 0.5^{a}$ & $89.6 \pm 0.5^{\mathrm{ab}}$ & $89.7 \pm 0.8^{\mathrm{ab}}$ & $86.9 \pm 2.1^{b}$ & $88.4 \pm 1.8^{\mathrm{ab}}$ \\
\hline Tyrosine & $92.0 \pm 2.8$ & $92.8 \pm 0.8$ & $90.8 \pm 0.8$ & $90.6 \pm 1.2$ & $92.1 \pm 1.0$ & $91.8 \pm 0.9$ \\
\hline Valine $^{1}$ & $90.8 \pm 1.4$ & $91.5 \pm 0.7$ & $89.6 \pm 0.6$ & $90.3 \pm 0.9$ & $88.7 \pm 2.1$ & $90.1 \pm 1.7$ \\
\hline
\end{tabular}

Values are given as mean \pm standard deviation.

${ }^{1}$ Indispensable amino acid (IAA).

\section{Discussion}

\section{Growth performance and feed efficiency}

Based on the present results, no significant differences were found between fish fed the higher inclusions of fishmeal (25.7\% of total ingredients), fish fed $15 \%$ (diet 4 ) and $0 \%$ fishmeal (diet 6), respectively. SGR and PER were generally high when compared with results obtained by Balogun \& Ologhobo (1989), Degani et al. (1989) and Hoffman et al. (1997) with African catfish of comparable size fed diets containing various proportions of FM and plant products, as well as with the results of Fagbenro (1999) who used 40\% menhaden FM, poultry by-product meal and maize meal to ensure crude protein levels of $400 \mathrm{~g} \mathrm{~kg}^{-1}$ diet. This supports the suggestion that the correct complementary mixture of plant and animal by-products can partly or totally replace the FM in Clarias diets. However, voluntary feed intake was significantly $(P<0.05)$ lower in Clarias fed diet 5 when compared with other diets. Similarly, all nutritional indices for fish fed diet $5(0 \% \mathrm{FM})$ were significantly $(P<0.05)$ inferior to those of fish fed diet $3(25 \% \mathrm{FM})$. This latter diet was different from the first two (D1 and D2) in terms of plant by-product content. While the 2 first diets contained only sunflower oilcake, a part of that oilcake was substituted by BM in the third diet. It was apparent that Clarias fingerlings might be sensitive to a large (higher than 25.7\%) inclusion of hulled sunflower oil cake for several reasons. Firstly, because of the high fibre content in SFOC, and secondly because the complementary nature of SFOC and BM leads to a better essential AA balance. Differences between diets 5 and 6 can only be explained by the dehulling of sunflower. Fishmeal can thus be totally replaced by a combination of groundnut oilcake, BM and sunflower oilcake, providing that sunflower oilcake is dehulled before its incorporation into the diet. Diets 1 and 2 provided similar results; the soaking of sunflower oilcake did not affect these results, whereas dehulling improved its nutritive value.

\section{Apparent digestibility coefficients}

The results of the present study showed that soluble and insoluble fibre levels decreased appreciably in diets with SFOCD when compared with SFOCS and SFOC. Dry 
matter digestibility coefficients ranged from a minimum of $60.5 \%$ (D1) to a maximum of $72.1 \%$ (D4). All diets containing a high level of hulled SFOC meal were less digestible. The low digestibility of dry matter and energy was probably due to the high fibre (ADF and NDF) content of the diet. Pre-treatment of SFOC ingredients appeared to be relatively important when considering the high digestibility coefficients recorded for all the diets evaluated. Soaking had little effect on ADC of dry matter and energy, whereas dehulling appeared to be the most effective method improving both dry matter and energy ADCs. Both soaking and dehulling enhanced starch digestibility by reduction of phytates and tannins which inhibit activity of $\alpha$-amylase. On the contrary, rupture of starch granules in plant feedstuffs during heat treatment makes substrates accessible and facilitates the amylolysis (Deshpende \& Cheryan 1984 in Alonso et al. 2000).

Protein digestibility coefficients were very similar ranging from 87.7 (D1, 25\% FM, SFOC) to 89.5\% (D6, 0\% FM, SFOCD). These results were consistent with the range of protein digestibility values (75-95\%) reported for other freshwater fish fed practical selected diets (Kenan \& Yasar 2005). Diets that contained a high level of animal protein and those composed principally of plant-based ingredients were all highly digestible. Improvement of protein digestibility could be attributable to the reduction or elimination of different anti-nutrients during the pre-treatment process, especially phytic acid and tannins which are known to interact with protein to form complexes. This can be also related to higher efficiency of the thermal treatment, reducing trypsin and chymotrypsin inhibitory activities (Alonso et al. 2000). The present results are higher than the protein ADC of soybean meal reported for channel catfish, I. punctatus (Brown et al. 1985), C. isheriensis (Fagbenro 1996) and higher than the protein ADC reported for C. gariepinus fed various dietary oilseed cakes (Fagbenro 1998). On the contrary, the present values were lower than the $92.8 \%$ for menhaden FM reported for C. gariepinus (Fagbenro 1998). Indispensable AA profiles in each diet were in agreement with Clarias requirements and all IAA had globally high ADCs (about 90\%). The present results suggest that FM can be replaced by plant feed stuffs in Clarias diets without AA supplementation when an adequate mixture of plant feedstuffs is used. Highest AA ADCs were found for arginine and lysine and this effect is relevant given the high requirements for these two AA in Clarias (Oellermann \& Hecht 2000; Wilson 2002).

Gross energy digestibility coefficients ranged from 71 to $81 \%$. The difference in gross energy ADCs in the present study may be attributed to differences in fibre content (Table 1). These results were higher than the $68.9 \%$ for cottonseed cake and similar to the 75.8 and $79 \%$ (except for D1 and D5) for groundnut cake, sunflower cake and soybean cake, respectively, reported for C. gariepinus (Fagbenro 1998). Björck et al. (1984 in Cheng \& Hardy 2003) suggested that the increased soluble fibre portion would improve ADCs of fibre and thus increase digestible energy, because non-ruminant animals (such as pigs) could utilize the fibre to meet $30-50 \%$ of their energy needs via fermentation to volatile fatty acids. Results of the present study suggest that this is not true in African catfish.

\section{Anti-nutritional factors}

Anti-nutritional factors are present in sunflower oilcakes and groundnut oilcake in similar proportions, whereas BM contained less phytic acid and displayed less antitryptic activity. Both soaking and dehulling of sunflower before incorporation helped in the reduction of trypsin inhibitors and tannins but not phytate. It was not possible to assay tannins in BM because of pigment interference. According to Deshpande et al. (1982 in Maldonado et al. 1995), it is clear that major amounts of bean tannins are located in the seed coat with lower or negligible amounts in the cotyledons. Tannin content should be determined using another analytical method for BM and the respective diets. Results for ANFs (Table 5)

Table 5 Proximate levels of anti-nutritional factors (ANFs) in the experimental ingredients and diets

\begin{tabular}{|c|c|c|c|}
\hline & \multicolumn{3}{|l|}{ ANFs } \\
\hline & $\begin{array}{l}\text { Trypsin } \\
\text { inhibitors } \\
\left(I \mathrm{I} \mathrm{g}^{-1}\right)\end{array}$ & $\begin{array}{l}\text { Phytate } \\
\left(\mathrm{g} \mathrm{kg}^{-1}\right)\end{array}$ & $\begin{array}{l}\text { Tannin } \\
\left(\mathrm{g} \mathrm{kg}^{-1}\right)\end{array}$ \\
\hline \multicolumn{4}{|l|}{ Ingredients } \\
\hline Bean meal (BM) & 4305 & 27.68 & nd \\
\hline Groundnut oilcake (GOC) & 4605 & 37.15 & 3.40 \\
\hline $\begin{array}{l}\text { Sunflower oilcake, crude } \\
\text { (SFOC) }\end{array}$ & 5547 & 36.00 & 9.34 \\
\hline $\begin{array}{l}\text { Sunflower oilcake, soaked } \\
\text { (SFOCS) }\end{array}$ & 4999 & 40.63 & 7.77 \\
\hline $\begin{array}{l}\text { Sunflower oilcake, dehulled } \\
\text { (SFOCD) }\end{array}$ & 4741 & 39.22 & 4.22 \\
\hline \multicolumn{4}{|l|}{ Diets } \\
\hline D1: (SFOC) & 1838 & 26.69 & nd \\
\hline D2: (SFOCS) & 2830 & 24.77 & nd \\
\hline D3: (SFOC + BM) & 3749 & 24.07 & nd \\
\hline D4: (SFOCD + BM) & 5337 & 38.37 & nd \\
\hline D5: (SFOCS + GOC) & 5104 & 34.64 & nd \\
\hline D6: $(\mathrm{SFOCD}+\mathrm{GOC}+\mathrm{BM})$ & 5587 & 34.32 & nd \\
\hline
\end{tabular}

nd, not determined. 
in the ingredients suggested that those anti-nutrients were elevated in diets 4 to 6 which contained a great number of plant ingredients.

It has been reported that 5-6 g of phytic acid per kilogram can impair the growth of rainbow trout (Spinelli et al. 1983 in Richter et al. 2003), whereas 2\% inclusion of condensed tannin were shown to be tolerated without any adverse effect on growth (Becker \& Makkar 1999 in Richter et al. 2003). Even if ANF contents are higher in diets 4 to 6, they did not have any apparent impact on the husbandry performance of clarias juveniles, suggesting that these ANFs were not the main issues influencing responses in the present study.

Robinson et al. (1985) in Hendricks (2002), on the contrary, observed no effect of trypsin inhibitor levels as high as 3.6 Trypsin Inhibitor Units (TIU) in an experiment with channel catfish. Contrary to the results of Garg et al. (2003) on Indian carp Cirrhinus mrigala, ANF contents of our experimental diets had no influence on palatability, the feed intake of diets 4 and 6 being similar to that of diets 1 to 3 . Moreover, for juveniles fed the supplemented diets and the non-supplemented diets containing FM, survival was $100 \%$ and no deformity was reported, contrary to what had been observed in Atlantic salmon (Salmo salar) and common carp (Cyprinus carpio) when phytic acid level was increased in feed (Ogino \& Takeda 1976; Baeverfjord et al. 1998; Roy et al. 2002; Sugiura et al. 2004 in Helland et al. 2006). More investigations are needed to determine the sensitivity of African catfish to these ANFs. The results of this study would also suggest that BM would be a good substitute in Clarias feeds, not only because of its lysine contribution, but also thanks to its low content of ANFs.

In conclusion, plant ingredients can efficiently substitute fishmeal in African catfish diets. Dehulling and cooking processes improved digestibility of sunflower oilcake (SFOC) and reduced some of its ANF contents, such as tannin and trypsin inhibitors. The results of this study also suggest that fishmeal can be totally replaced by plant feedstuffs in Clarias diets, assuming that a proper balance of the different plant ingredients is ensured, without AA supplementation.

\section{Acknowledgements}

The authors thank the General Commissariat for the International Relationships (CGRI) and the Directorate of International Relationships (DRI) of the French Speaking Community Government and Ministry of Walloon of Belgium, respectively, for financial support to L. Nyinawamwiza and to the FUNDP-UNR project 'Filière Clarias'.
We would like to acknowledge Mr Yves Beckers (Gembloux University) for gross energy determination in his laboratory.

\section{References}

Abdel-El-Samei, M.H. \& Lasztity, R. (1984) Comparative study on the amino acids composition in three local Phaseolus vulgaris seeds varieties. Z. Lebensm. Unters. Fosch., 178, 24-26.

Aganda, A.A. \& Mosase, K.W. (2001) Tannin content, nutritive value and dry matter digestibility of Lonchocarpus capassa, Zizyphus mucronata, Sclerocarya birrea, Kirkia acuminata and Rhus lancea seeds. Anim. Feed. Sci. Technol., 91, 107-113.

Akpapunam, M.A. \& Sefa-Dedeh, S. (1997) Some physicochemical properties and anti-nutritional factors of raw, cooked and germinated Jack bean (Canavalia ensiformis). Food. Chem., 59, $121-125$.

Alonso, R., Orue, E. \& Marzo, F. (1998) Effects of extrusion and conventional processing methods on protein and antinutritional factor contents in pea seeds. Food. Chem., 63, 505-512.

Alonso, R., Aguire, A. \& Marzo, F. (2000) Effects of extrusion and traditional processing methods on antinutrients and in vitro digestibility of protein and starch in faba and kidney beans. Food. Chem., 68, 159-165.

Amrish, K.T. (2002) Influence of water soaking of mustard cake on glucosinolate hydrolysis. Anim. Feed. Sci. Technol., 99, 215219.

AOAC. (1980) Official methods of analysis. In: Association of Official Analytical Chemists (Horwitz, W. ed.), 13th edn, p. 1018. Washington, D.C.

Balogun, M.A. \& Ologhobo, D.A. (1989) Growth performance and nutrient utilization of fingerling Clarias gariepinus (Burchell) fed raw and cooked soy bean diets. Aquaculture, 76, 119-126.

Bergmeyer, H.U. (1965) Methods of Enzymatic Analysis. Academic Press, New York, p. 555.

Brown, P.B., Strange, R.J. \& Robbins, K.R. (1985) Protein digestibility coefficients for rearing channel catfish fed high protein feedstuffs. Prog. Fish Cult., 47, 94-97.

Burel, C., Boujard, T., Tulli, F. \& Kaushik, S.J. (2000) Digestibility of extrudes peas, extruded lupin, and rapeseed meal in rainbow trout (Oncorhynchus mykiss) and turbo (Psetta maxima). Aquaculture, 188, 285-298.

Cheng, Z.J. \& Hardy, R.W. (2003) Effect of extrusion processing of feed ingredients on apparent digestibility coefficients on nutrients for rainbow trout (Oncorhynchus mykiss). Aquac. Nutr., 9, 77-83.

Cho, C.Y. \& Slinger, S.J. (1979) Apparent digestibility measurement in feedstuffs for rainbow trout. in: Proceeding of the World Symposium on Finfish Nutrition and Fishfeed Technology (Harver, J. \& Tiews, K. eds), Vol. 2, pp. 239-247. Heenemann, Berlin.

Chong, A.S.C., Hashim, R. \& Ali, A.B. (2002) Assesment of dry matter and protein digestibilities of selected raw ingredients by discus fish (Symphysodon aequifasciata) using in vivo and in vitro methods. Aquac. Nutr., 8, 229-238.

Choubert, G., de la Noue, J. \& Luquet, P. (1982) Digestibility in fish: improved device for the automatic collection of faeces. Aquaculture, 29, 185-189.

Dagnelie, P. (1975) Théorie et Méthodes Statistiques, Vol. II. Presses Agronomiques de Gembloux, Belgique, pp. 463.

Degani, G., Ben-Zvi, Y. \& Levanon, D. (1989) The effect of different protein levels and temperatures on feed utilisation, growth and 
body composition of Clarias gariepinus (Burchell 1822). Aquaculture, 76, 293-301.

Desphande, S.S. \& Cheryan, M. (1985) Evaluation of vanillin assays for tannin analysis of dry beans. J. Food Sci., 50, 905-910.

Egounlety, M. \& Aworth, O.C. (2003) Effect of soaking, dehulling and fermentation with Rhizopus oligosporus on the oligosaccharides, trypsin inhibitor, phytic acid and tannins of soybean (Glycine max Merr.), cowpea (Vigna unguiculata L. Walp) and groundbean (Macrotyloma geocarpa Harms). J. Food Eng., 56, 249-254.

Fagbenro, O.A. (1996) Apparent digestibility of crude protein and gross energy in some plant and animal-based feedstuffs by Clarias isheriensis (Siluriformes: Clariidae). J. Appl. Ichthyol., 12, 67-68.

Fagbenro, O.A. (1998) Apparent digestibility of various oilseed cakes/meals in African catfish diets. Aquac. Int., 6, 317-322.

Fagbenro, O.A. (1999) Comparative evaluation of heat-processed winged bean (Psophocarpus tetragonolobus) meals as partial replacement for fish meal in diets for the African catfish (Clarias gariepinus). Aquaculture, 170, 297-305.

Folch, J., Lee, M. \& Sloane-Stanley, G.H. (1957) A simple method for the isolation and purification of total lipids from animal tissues. J. Biol. Chem., 226, 497-509.

Fournier, V., Huelvan, C. \& Desbruyeres, E. (2004) Incorporation of a mixture of plant feedstuffs as substitute for fish meal in diets of juvenile turbot (Psetta maxima). Aquaculture, 236, 451-465.

Francis, G., Makkar, H.P.S. \& Becker, K. (2001) Antinutritional factors present in plant-derived alternate fish feed ingredients and their effects in fish. Aquaculture, 199, 197-227.

Furukawa, A. \& Tsukahara, H. (1966) On the acid digestion of chromic oxide as an index substance in the study of digestibility of fish feed. Bull. Japan. Soc. Sci. Fish., 32, 502-506.

Garg, S.K., Alok, K. \& Bhatnagar, A. (2003) Oilcakes as protein sources in supplementary diets for the growth of Crrhinus mrigla (Ham) fingerlings: laboratory and field studies. Bioresour. Technol., 86, 283-291.

Gill, N., Higg, D.A., Skura, B.J., Rowshandeli, M., Dosanjh, B., Mann, J. \& Gannam, A.L. (2006) Nutritive value of partially dehulled and extruded sunflower meal for post-smolt Atlantic salmon (Salmo salar L.) in sea water. Aquac. Res., 37, 1348-1359.

Goering, H.K. \& van Soest, P.J. (1970) Forage Fiber Analyses (Apparatus, Reagents, Procedure and Some Applications). Agriculture Handbook No. 379ARS. USDA, Washington, D.C.

Gomes, E.F., Rema, P. \& Kaushik, S.J. (1995) Replacement of fish meal by plant proteins in the diet of rainbow trout (Oncorhynchus mykiss): digestibility and growth performance. Aquaculture, 130, 177-186.

Helland, S., Denstadli, V., Witten, P.E., Hjelde, K., Storebakken, T., Skrede, A., Asgard, T. \& Baeverfjord, G. (2006) Hyper dense vertebrae and mineral content in Atlantic salmon (Salmo salar L.) fed diets with graded levels of phytic acid. Aquaculture, 261, 603614.

Hendricks, J.D. (2002) Adventitious toxins. In: Fish Nutrition (Halver, J.E. \& Hardy, R.W. eds), 3rd edn, pp. 143-159. Academic Press, London.

Hoffman, L.C., Prinsloo, J.F. \& Rukan, G. (1997) Partial replacement of fish meal with either soybean meal, brewers yeast or tomato meal in the diets of African sharptooth catfish Clarias gariepinus. Water S.A., 23, 181-186.

Huisman, J.P., Van der Poel, A.F.B. \& Liener, I.E. (eds) 1989) Recent Advances of Research in Antinutritional Factors in Legume Seeds. Pudoc, Wageningen, p. 389.
Kaushik, S.J., Cravedi, J.P., Lalles, J.P., Sumpter, J., Fauconneau, B. \& Laroche, M. (1995) Partial or total replacement of fish meal by soybean protein on growth, protein utilisation, potential estrogenic or antigenic effects cholesterolemia and flesh quality in raimbow trout, Oncorhynchus mykiss. Aquaculture, 133, 257274.

Kaushik, S.J., Covès, D., Dutto, G. \& Blanc, D. (2004) Almost total replacement of fish meal by plant protein sources in the diet of a marine teleost, the European seabass, Dicentrarchus labrax. Aquaculture, 230, 391-404.

Kenan, K. \& Yasar, Ö. (2005) Apparent digestibility of selected feed ingredients for Nile tilapia (Oreochromis niloticus). Aquaculture, 250, 308-316.

Koplik, R., Mestek, O., Kominkova, J., Borkova, M. \& Suchanek, M. (2004) Effect of cooking on phosphorus and trace elements species in peas. Food. Chem., 85, 31-39.

Krogdahl, A. (1989) Alternative protein sources from plants contain antinutrients affecting digestion in salmonids. In: Proceedings of the Third International Symposium on Feeding and Nutrition in Fish (Takeda, M. \& Watanabe, T. eds), pp. 253261. Toba, Japan.

Lewis, O. (1966) Short ion-exchange column method for the estimation of cystine and methionine. Nature, 209, 1239-1241.

Lienner, I.E. (1980) Toxic Constituents of Plant Foodstuffs, 2nd edn. Academic Press, New York, p. 502.

Maldonado, H.G., Castellanos, J. \& Gonzalez de Mejia, E. (1995) Relationship between theoretical and experimentally detected tannin content of common beans (Phaseolus vulgaris L.). Food. Chem., 55, 333-335.

Mambrini, M. \& Kaushik, S.J. (1995) Indispensable amino acid requirement of fish: correspondence between quantitative data and amino acid profiles of tissue proteins. J. Appl. Ichthyol., 11, 240247.

March, J.G., Villacampa, A.I. \& Grases, F. (1995) Enzymaticspectrophotometric determination of phytic acid with phytase from Aspergillus ficuum. Anal. Chim. Acta, 300, 269-272.

Masumoto, T., Ruchimat, T., Ito, Y., Hosokawa, H. \& Shimeno, S. (1996) Amino acid availability values for several protein sources for yellowtail (Seriola quinqueradiata). Aquaculture, 146, $109-119$.

Moore, S., Spackman, D. \& Stein, W. (1958) Chromatography of amino acid on polystyrene sulfonated resins. Anal. Chem., 30, $1185-1200$.

Nibedita, M. \& Sukumar, B. (2003) Extrusion cooking technology employed to reduce the anti-nutritional factor tannin in sesame (Sesamum indicum) meal. J. Food Eng., 56, 201-202.

Nyina-wamwiza, L., Wathelet, B. \& Kestemont, P. (2007) Potential of local agricultural by-products for the rearing of African catfish, Clarias gariepinus in Rwanda: effects on growth, feed utilization and body composition. Aquac. Res., 38, 206-214.

Oellermann, L.K. \& Hecht, T. (2000) Comparison of the fillet yield, protein content and amino acid profile of Clarias gariepinus and the Clarias gariepinus $\times$ Heterobranchus longifilis hybrid. Aquac. Res., 31, 553-556.

Regost, C., Arzel, J. \& Kaushik, S.J. (1999) Partial or total replacement of fish meal by corn gluten meal for turbot (Psetta maxima). Aquaculture, 180, 99-117.

Richter, N., Siddhuraju, P. \& Becker, K. (2003) Evaluation of nutritional quality of moringa (Moringa oleifera Lam) leaves as an alternative protein source for Nile tilapia (Oreochromis niloticus L.). Aquaculture, 217, 599-611. 
Robaina, L., Izquierdo, M.S., Moyano, F.J., Socorro, J., Vergara, J.M., Montero, D. \& Fernandez Palacios, H. (1995) Soybean and lupin seed meals as protein sources in diets for gilthead seabream (Sparus aurata): nutritional and histological implication. Aquaculture, 130, 219-233.

Sajjadi, M. \& Carter, C.G. (2004) Effect of phytic acid and phytase on feed intake, growth digestibility and trypsin activity in Atlantic salmon (Salmo salar, L.). Aquac. Nutr., 10, 135-142.

Sauvant, D., Perez, J.M. \& Tran, G. (2002) Tables de composition et de valeur nutritive des matières premières destinées aux animaux d'élevage. INRA, Paris, p. 301.
Sen, M. \& Bhattacharyya, D.K. (2000) Nutritional quality of sunflower seed protein fraction extracted with isopropanol. Plant Foods Hum. Nutr., 55, 265-278.

Van Weerd, J.H. (1995) Nutrition and growth in Clarias species. A review. Aquat. Living Resour., 8, 395-401.

Webster, C.D. \& Lim, C. (2002) Nutrient Requirements and Feeding of Finfish for Aquaculture. CABI Publishing, p. 418.

Wilson, R.P. (2002) Amino acids and proteins. in: Fish Nutrition (Halver, J.E. \& Hardy, R.W. eds), 3rd edn, pp. 143-159. Academic Press, London. 